\title{
Peningkatan kualitas planlet tanaman pisang raja bulu (Musa paradisiaca) dengan penambahan bap dan iaa pada media pengakaran kultur in vitro
}

\author{
(Quality improvement of plantlet of banana CV. raja bulu (Musa paradisiaca) by \\ addition of Benzyl Amino Purine (BAP) and Indole Acetic Acid (IAA) to in vitro culture \\ rooting media)
}

\author{
R. T. Nofiyanto, F. Kusmiyati, dan Karno \\ Agroecotechnology, Faculty of Animal and Agricultural Sciences, \\ Diponegoro University \\ Tembalang Campus, Semarang 50275 - Indonesia \\ Corresponding E-mail:rizaltry99@gmail.com
}

\begin{abstract}
The study was to examine the effect of addition of Benzyl Amino Purine (BAP) and Indole Acetic Acid (IAA) to tissue culture rooting media on growth of banana CV. raja bulu (Musa paradisiaca). The study was conducted at the Salaman Horticultural Seed Garden Tissue Culture Laboratory, Magelang in June to August 2018. The research design used was factorial completely randomized design. The first factor was BAP hormone with a concentration of $0 ; 0.5 ; 1 ; 1.5$; and $2 \mathrm{ppm}$, the second factor was IAA hormone with a concentration of $0,1,2,3$, and $4 \mathrm{ppm}$. The combination of treatments was 25 with 4 replications, there were 100 units of experiment which each unit consisted of 5 banana cv. raja bulu plantlets. The results showed that there was influence of interaction between BAP and IAA treatment on growth parameter of raja bulu banana plantlet. The combination of $1 \mathrm{ppm}$ BAP $+3 \mathrm{ppm}$ IAA gave the best effect on the number of leaves and stem diameter, while the combination of $0.5 \mathrm{ppm} \mathrm{BAP}+4 \mathrm{ppm}$ IAA gave the best effect on root and root length. The combination of $1.5 \mathrm{ppm}$ BAP $+4 \mathrm{ppm}$ IAA gave the best effect on plantlet height. The conclusion of this study was the plant growth regulator $0.5-1.5$ ppm BAP + 3 - 4 ppm IAA was recommended for banana cv. raja bulu tissue culture media.
\end{abstract}

Keywords: in vitro, BAP, IAA, plantlet, banana.

\begin{abstract}
ABSTRAK
Penelitian ini bertujuan untuk mengkaji pengaruh penambahan BAP dan IAA pada media pengakaran kultur jaringan terhadap pertumbuhan tanaman pisang raja bulu (Musa paradisiaca). Penelitian dilaksanakan di Laboratorium Kultur Jaringan Kebun Benih Hortikultura Salaman, Magelang pada bulan Juni hingga Agustus 2018. Rancangan penelitian yang digunakan adalah Rancangan Acak Lengkap (RAL) faktorial dengan 4 (empat) kali ulangan. Faktor pertama adalah hormon BAP dengan konsentrasi masing-masing $0 ; 0,5 ; 1 ; 1,5$; dan $2 \mathrm{ppm}$, faktor kedua yaitu hormon IAA dengan konsentrasi $0,1,2,3$, dan 4 ppm. Kombinasi perlakuan sebanyak 25 dengan 4 kali ulangan, sehingga terdapat 100 unit percobaan yang setiap unit percobaan terdiri dari 5 planlet pisang raja bulu. Hasil penelitian menunjukkan bahwa terdapat pengaruh interaksi perlakuan BAP dan IAA terhadap parameter pertumbuhan planlet pisang raja bulu. Kombinasi BAP 1 ppm + IAA 3 ppm memberikan pengaruh terbaik pada jumlah daun dan diameter batang, sedangkan kombinasi BAP 0,5 ppm + IAA 4 ppm memberikan pengaruh terbaik pada jumlah akar dan panjang akar. Kombinasi BAP 1,5 ppm + IAA 4 ppm memberikan pengaruh terbaik pada tinggi planlet. Kesimpulan dari penelitian ini adalah zat pengatur tumbuh BAP $0,5-1,5 \mathrm{ppm}+$ IAA $3-4 \mathrm{ppm}$ direkomendasikan untuk media pengakaran kultur jaringan pisang raja bulu.

Kata kunci: in vitro, BAP, IAA, plantlet, pisang
\end{abstract}


Tabel 1. Komposisi Media MS dari Larutan Stok

\begin{tabular}{|c|c|c|c|c|}
\hline $\begin{array}{l}\text { Nama } \\
\text { Stok }\end{array}$ & Senyawa & $\begin{array}{c}\text { komposisi } \\
\text { stok } \\
\text { (per liter) }\end{array}$ & $\begin{array}{l}\text { Komposisi } \\
\text { Media MS } \\
\text { (per liter) }\end{array}$ & $\begin{array}{l}\text { Volume yang dipipet } \\
\text { (per } 2 \text { liter media) }\end{array}$ \\
\hline $\mathrm{A}$ & $\mathrm{NH}_{4} \mathrm{NO}_{3}$ & $82,500 \mathrm{~g}$ & $1,650 \mathrm{mg}$ & $40 \mathrm{ml}$ \\
\hline $\mathrm{B}$ & $\mathrm{KNO}_{3}$ & $95,000 \mathrm{~g}$ & $1,900 \mathrm{mg}$ & $40 \mathrm{ml}$ \\
\hline \multirow{5}{*}{$\mathrm{C}$} & $\mathrm{KH}_{2} \mathrm{PO}_{4}$ & $34,000 \mathrm{~g}$ & $170,000 \mathrm{mg}$ & \multirow{5}{*}{$10 \mathrm{ml}$} \\
\hline & $\mathrm{H}_{3} \mathrm{BO}_{3}$ & $1,240 \mathrm{~g}$ & $6,200 \mathrm{mg}$ & \\
\hline & $\mathrm{Na}_{2} \mathrm{MoO}_{4} 2 \mathrm{H}_{2} \mathrm{O}$ & $0,050 \mathrm{~g}$ & $0,250 \mathrm{mg}$ & \\
\hline & $\mathrm{CoCl}_{2} 6 \mathrm{H}_{2} \mathrm{O}$ & $0,005 \mathrm{~g}$ & $0,025 \mathrm{mg}$ & \\
\hline & $\mathrm{Kl}$ & $0,166 \mathrm{~g}$ & $0,830 \mathrm{mg}$ & \\
\hline $\mathrm{D}$ & $\mathrm{CaCl}_{2} 2 \mathrm{H}_{2} \mathrm{O}$ & $88,000 \mathrm{~g}$ & $440,000 \mathrm{mg}$ & $10 \mathrm{ml}$ \\
\hline \multirow{4}{*}{$\mathrm{E}$} & $\mathrm{MgSO}_{4} 7 \mathrm{H}_{2} \mathrm{O}$ & $74,000 \mathrm{~g}$ & $370,000 \mathrm{mg}$ & \multirow{4}{*}{$10 \mathrm{ml}$} \\
\hline & $\mathrm{MnSO}_{4} 4 \mathrm{H}_{2} \mathrm{O}$ & $4,460 \mathrm{~g}$ & $22,300 \mathrm{mg}$ & \\
\hline & $\mathrm{ZnSO}_{4} 7 \mathrm{H}_{2} \mathrm{O}$ & $1,720 \mathrm{~g}$ & $8,600 \mathrm{mg}$ & \\
\hline & $\mathrm{CuSO}_{4} 5 \mathrm{H}_{2} \mathrm{O}$ & $0,005 \mathrm{~g}$ & $0,025 \mathrm{mg}$ & \\
\hline \multirow[t]{3}{*}{$\mathrm{F}$} & $\mathrm{Na}_{2} \mathrm{EDTA}$ & $7,460 \mathrm{~g}$ & $37,300 \mathrm{mg}$ & \multirow[t]{2}{*}{$10 \mathrm{ml}$} \\
\hline & $\mathrm{FeSO}_{4} 7 \mathrm{H}_{2} \mathrm{O}$ & $5,400 \mathrm{~g}$ & $27,000 \mathrm{mg}$ & \\
\hline & Tiamin $\mathrm{HCl}$ & $0,020 \mathrm{~g}$ & $0,100 \mathrm{mg}$ & \multirow{3}{*}{$10 \mathrm{ml}$} \\
\hline \multirow[t]{2}{*}{ VIT } & Asam Nikotinat & $0,100 \mathrm{~g}$ & $0,500 \mathrm{mg}$ & \\
\hline & Pyridoksin $\mathrm{HCl}$ & $0,100 \mathrm{~g}$ & $0,500 \mathrm{mg}$ & \\
\hline & Myoinositol & $10,000 \mathrm{~g}$ & $100,000 \mathrm{mg}$ & $20 \mathrm{ml}$ \\
\hline & Sukrosa & - & - & $60,000 \mathrm{gr}$ \\
\hline & Agar & - & - & $14,000 \mathrm{gr}$ \\
\hline
\end{tabular}

*Kebun Benih Hortikultura Salaman, 2017.

\section{PENDAHULUAN}

Tanaman pisang (Musa paradisiaca) termasuk ke dalam divisi Magnoliophyta, kelas Liliopsida, ordo Zingiberales, famili Musaceae (Saparinto dan Susiana, 2016). Tanaman pisang banyak dibudidayakan di negara-negara Asia Tenggara seperti negara Indonesia, namun tanaman pisang juga telah menyebar ke daerah Afrika, Amerika Tengah dan Amerika Selatan. Tanaman pisang berkembang biak secara vegetatif melalui tunas, namun untuk kegiatan produksi tanaman pisang tidak bisa mengandalkan proses perkembangbiakan secara alami melalui tunas. Kultur jaringan tanaman pisang merupakan usaha yang banyak diterapkan untuk memenuhi kebutuhan yang semakin meningkat (Yudha et al., 2015). Media yang digunakan dalam kultur jaringan mempunyai banyak jenisnya, salah satunya adalah Murashige and Skoog (MS). Media MS terdiri dari unsur hara makro, mikro, vitamin, serta zat pengatur tumbuh (ZPT) untuk menunjang pertumbuhan tunas tanaman pisang.

Zat pengatur tumbuh yang biasa digunakan dalam kultur jaringan antara lain Indol Acetic Acid (IAA), Naphthalene Acetic Acid (NAA), Benzyl Amino Purine (BAP), dan Indole 3-Butyric Acid (IBA) (Yuliarti, 2010). Benzyl Amino Purine (BAP) merupakan ZPT dari golongan sitokinin yang berfungsi untuk menginduksi pembentukan tunas adventif dari eksplan pisang (Bhosale et al., 2011). Indol Acetic Acid (IAA), Naphthalene Acetic Acid (NAA), dan Indole 3-Butyric Acid (IBA) merupakan zat pengatur tumbuh dari golongan auksin, ZPT ini berpengaruh pada perkembangan sel dan berfungsi untuk merangsang pertumbuhan akar eksplan tanaman (Amin et al., 2009). Penelitian Yudha et al. (2015) menunjukkan bahwa respon pembentukan tunas pisang terbaik tanaman pisang barangan diperoleh dari kombinasi perlakuan NAA $1,5 \mathrm{mg} / \mathrm{l}$ dan BAP $5 \mathrm{mg} / 1$ dengan jumlah tunas rata-rata 3,75 dan 
panjang tunas rata-rata $2,30 \mathrm{~cm}$. Anbazhagan et al. (2014) melaporkan bahwa kombinasi BAP $3 \mathrm{mg} / \mathrm{l}$ dan IAA $0,5 \mathrm{mg} / \mathrm{l}$ memberikan pengaruh terbaik terhadap pertumbuhan tunas pisang. Penelitian yang dilakukan Ahmed et al. (2014) menunjukkan bahwa pertumbuhan tunas pisang tercepat diperoleh dari kombinasi perlakuan IAA $2 \mathrm{mg} / \mathrm{l}$ dan BAP 4 mg/l. Yatim (2016) melaporkan bahwa pemberian BAP dengan dosis 2 dan 3 ppm pada media MS memberikan pengaruh terbaik pada pertumbuhan daun planlet pisang raja bulu.

Tujuan dari penelitian ini adalah untuk mengkaji pengaruh dari perlakuan BAP dan IAA terhadap pertumbuhan planlet pisang raja bulu (Musa paradisiaca). Manfaat penelitian ini adalah dapat memberikan rekomendasi penambahan dosis BAP dan IAA pada media pengakaran kultur jaringan tanaman pisang raja bulu (Musa paradisiaca).

\section{MATERI DAN METODE}

Penelitian ini dilaksanakan pada bulan Juni Agustus 2018 di Laboratorium Kultur Jaringan Kebun Benih Hortikultura Salaman, Magelang.

\section{Materi Penelitian}

Alat yang diperlukan dalam penelitian ini antara lain autoclaf, laminar air flow, pinset, scapel, gelas beker, hot plate strirer, cawan petri, botol kaca, rak kultur, kapas, timbangan, kertas dan karet gelang, bunsen, spatula, $\mathrm{pH}$ meter. Bahan yang digunakan dalam penelitian ini antara lain alkohol 96\%, aquades, $\mathrm{NaOH} 1 \mathrm{~N}, \mathrm{HCl} 1 \mathrm{~N}$, hormon BAP dan IAA, makronutrien, mikronutrien, vitamin, agar-agar, gula pasir, dan myo-inositol. Planlet yang digunakaan adalah varietas pisang raja bulu hasil subkultur ke-6 dengan kriteria mempunyai tiga daun, tinggi planlet $3-3,5 \mathrm{~cm}$, dan diameter batang $0,25 \mathrm{~cm}$.

\section{Rancangan Percobaan}

Rancangan percobaan yang digunakan dalam penelitian ini adalah Rancangan Acak Lengkap (RAL) faktorial. Faktor pertama adalah hormon BAP dengan taraf masing-masing $0 ; 0,5 ; 1 ; 1,5$; dan $2 \mathrm{ppm}$. Faktor kedua yaitu hormon IAA dengan taraf $0,1,2,3$, dan 4 ppm. Masing-masing perlakuan diulang sebanyak $4 \mathrm{kali}$, sehingga terdapat 100 unit percobaan. Data yang diperoleh dianalisis menggunakan analisis ragam untuk mengetahui pengaruh perlakuan, dilanjutkan dengan pembandingan nilai tengah dengan Duncan MultipleRange Test (DMRT) pada taraf 5 $\%$ untuk mengetahui perbedaan antar perlakuan. Parameter yang diamati antara lain jumlah daun, jumlah akar, panjang akar, tinggi planlet, dan diameter batang.

\section{Metode Pelaksanaan}

Pelaksanaan penelitian dilakukan dalam beberapa tahap, antara lain adalah sterilisasi alat, pembuatan media, dan transplanting planlet. Sterilisasi pinset, scapel, gelas beker, dan cawan petri dilakukan dengan cara membungkusnya dengan kertas dan diikat menggunakan karet gelang, kemudian disterilisasi menggunakan autoclave selama 30 menit dengan suhu $121{ }^{\circ} \mathrm{C}$ dan tekanan 17,5 Psi. Planlet dan scapel disterilisasi menggunakan alkohol dan dibakar di

Tabel 2. Rata-rata Jumlah Daun pada Perlakuan BAP dan IAA

\begin{tabular}{|c|c|c|c|c|c|c|}
\hline \multirow{2}{*}{ BAP (ppm) } & \multicolumn{5}{|c|}{ IAA (ppm) } & \multirow{2}{*}{ Rata-rata } \\
\hline & 0 & 1 & 2 & 3 & 4 & \\
\hline & & & & helai---- & ---------- & ----- \\
\hline 0 & $1,15^{\mathrm{cd}}$ & $2,50^{\mathrm{ab}}$ & $1,85^{\mathrm{ab}}$ & $0,90^{\mathrm{d}}$ & $2,15^{\mathrm{ab}}$ & $1,71^{\mathrm{c}}$ \\
\hline 0,5 & $2,45^{\mathrm{ab}}$ & $2,05^{\mathrm{ab}}$ & $1,75^{\mathrm{ab}}$ & $0,70^{\mathrm{d}}$ & $2,45^{a b}$ & $1,88^{\mathrm{bc}}$ \\
\hline 1 & $1,80^{a b}$ & $1,75^{b c}$ & $1,90^{a b c}$ & $2,75^{\mathrm{a}}$ & $2,10^{a b}$ & $2,06^{\mathrm{ab}}$ \\
\hline 1,5 & $1,80^{\mathrm{ab}}$ & $2,25^{\mathrm{ab}}$ & $2,65^{\mathrm{a}}$ & $1,95^{\mathrm{abc}}$ & $2,30^{\mathrm{ab}}$ & $2,19^{\mathrm{ab}}$ \\
\hline 2 & $1,95^{\mathrm{abc}}$ & $2,20^{\mathrm{ab}}$ & $2,75^{\mathrm{a}}$ & $2,30^{\mathrm{ab}}$ & $2,30^{\mathrm{ab}}$ & $2,30^{\mathrm{a}}$ \\
\hline Rata-rata & $1,83^{\mathrm{c}}$ & $2,15^{\text {bc }}$ & $2,18^{\mathrm{ab}}$ & $1,72^{\mathrm{ab}}$ & $2,26^{\mathrm{a}}$ & \\
\hline
\end{tabular}


atas api bunsen pada saat transplanting. Sterilisasi laminar airflow dilakukan dengan cara dibersihkan dengan alkohol menggunakan kapas dan menyalakan lampu UV selama 60 menit sebelum melakukan multiplikasi. Sterilisasi ruangan dilakukan dengan cara membersihkan kotoran dalam ruangan dan menyemprot ruangan dengan formalin, kemudian diinkubasi selama 24 jam. Rak inkubasi media dan tempat menumbuhkan planlet dibersihkan menggunakan alkohol.

Pembuatan media dilakukan dengan cara memasukkan larutan stok (A - G), myo-inositol, dan sukrosa ke dalam labu ukur dengan volume sesuai pada Tabel 1. Kemudian aquades ditambahkan ke dalam media hingga volumenya mencapai 2 liter, lalu dihomogenkan menggunakan stirer.

Media yang telah homogen dibagi ke dalam 25 gelas beker ukuran $150 \mathrm{ml}$ dengan volume masing-masing $50 \mathrm{ml}$. Kemudian zat pengatur tumbuh BAP dan IAA dimasukkan ke dalam masing-masing media sesuai dengan dosis perlakukan. Selanjutnya, aquades ditambahkan ke dalam masing-masing media hingga volumenya mencapai $100 \mathrm{ml}$.

Masing-masing media pada gelas beker diukur pHnya menggunakan $\mathrm{pH}$ meter. Media yang baik mempunyai $\mathrm{pH}$ antara 5,6 - 5,8. Apabila pH kurang dari 5,6 maka ditambahkan beberapa tetes $\mathrm{NaOH}$ dan jika $\mathrm{pH}$ lebih dari 5,8 ditambahkan HCL $1 \mathrm{~N}$ untuk menurunkan $\mathrm{pH}$ media. Setelah itu masing-masing media ditambahkan agar-agar sebanyak 0,7 gr dan karbon aktif sebanyak 0,075 gr, lalu diaduk dan dimasak menggunakan hot plate stirer hingga mendidih. Setelah mendidih, media dituangkan ke dalam botol dengan volume masing-masing $25 \mathrm{ml}$ lalu ditutup rapat.

Tahap selanjutnya yaitu botol yang telah berisi media dengan masing-masing perlakuan disterilisasi menggunakan autoclave selama 30 menit dengan suhu $121{ }^{\circ} \mathrm{C}$ dan tekanan 17,5 psi. Setelah disterilisasi, media diinkubasi selama 7 hari untuk mengetahui ada atau tidaknya kontaminan.

Transplantasi planlet pisang raja bulu dilakukan di dalam laminer airflow menggunakan alas cawan petri. Planlet diambil dari botol multiplikasi lama menggunakan pinset, kemudian daun dan akar yang tumbuh dibersihkan menggunakan scapel, lalu diukur menggunakan penggaris yang ditempatkan di bawah cawan petri. Selanjutnya planlet dimasukkan ke dalam botol berisi media yang telah dibuat dengan jumlah masing-masing lima planlet. Setelah itu, botol ditutup rapat dan diberi wrap plastic pada leher botol, kemudian diletakkan di rak dalam ruang pertumbuhan.

\section{HASIL DAN PEMBAHASAN}

\section{Jumlah Daun}

Hasil analisis ragam menunjukkan bahwa perlakuan BAP dan IAA memberikan pengaruh nyata terhadap jumlah daun planlet pisang raja bulu. Interaksi perlakuan BAP dan IAA juga memberikan pengaruh nyata terhadap jumlah daun planlet pisang raja bulu, (Tabel 2).

Berdasarkan Tabel 2 diketahui bahwa

Tabel 3. Rata-rata Jumlah Akar pada Perlakuan BAP dan IAA

\begin{tabular}{|c|c|c|c|c|c|c|}
\hline \multirow{2}{*}{ BAP (ppm) } & \multicolumn{5}{|c|}{ IAA (ppm) } & \multirow[t]{2}{*}{ Rata-rata } \\
\hline & 0 & 1 & 2 & 3 & 4 & \\
\hline & \multicolumn{6}{|c|}{ 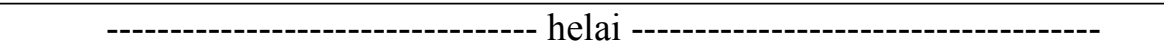 } \\
\hline 0 & $1,70^{\text {ef }}$ & $3,75^{\mathrm{ab}}$ & $2,85^{\text {abcde }}$ & $2,00^{\text {def }}$ & $3,50^{\mathrm{abc}}$ & $2,76^{\mathrm{b}}$ \\
\hline 0,5 & $2,95^{\text {abcde }}$ & $2,55^{\text {bcdef }}$ & $3,45^{\mathrm{abc}}$ & $1,35^{\mathrm{f}}$ & $4,20^{\mathrm{a}}$ & $2,90^{\mathrm{ab}}$ \\
\hline 1 & $3,75^{\mathrm{ab}}$ & $2,70^{\text {bcde }}$ & $2,20^{\text {cdef }}$ & $3,90^{\mathrm{ab}}$ & $3,63^{\mathrm{abc}}$ & $3,24^{\mathrm{a}}$ \\
\hline 1,5 & $3,75^{\mathrm{ab}}$ & $3,75^{\mathrm{ab}}$ & $3,45^{\mathrm{abc}}$ & $3,60^{\mathrm{ab}}$ & $2,95^{\text {abcde }}$ & $3,50^{\mathrm{b}}$ \\
\hline 2 & $2,15^{\text {cdef }}$ & $3,10^{\text {abcd }}$ & $3,75^{\mathrm{ab}}$ & $3,00^{\text {abcde }}$ & $3,05^{\text {abcd }}$ & $3,01^{\mathrm{ab}}$ \\
\hline Rata-rata & 2,86 & 3,17 & 3,14 & 2,77 & 3,47 & \\
\hline
\end{tabular}


terdapat pengaruh interaksi antara perlakuan BAP dan IAA terhadap parameter jumlah daun planlet pisang raja bulu (Musa paradisiaca). Perlakuan BAP 0,5 ppm mengalami penurunan rata-rata hasil jumlah daun pada konsentrasi IAA 1 ppm hingga 3 ppm, namun kembali naik secara signifikan pada perlakuan IAA $4 \mathrm{ppm}$. Sedangkan perlakuan BAP 1,5 ppm mengalami kenaikan rata-rata hasil jumlah daun pada perlakuan IAA 1 ppm hingga 2 ppm, namun sama-sama mengalami penurunan pada perlakuan IAA $3 \mathrm{ppm}$ dan kenaikan rata-rata jumlah daun pada perlakuan IAA 4 ppm. Perlakuan BAP 1 ppm tidak memberikan hasil yang jauh berbeda pada perlakuan IAA $0 \mathrm{ppm}$ hingga $2 \mathrm{ppm}$, namun pada perlakuan IAA $3 \mathrm{ppm}$ justru mengalami kenaikan rata-rata jumlah daun dan pada perlakuan IAA 4 ppm mengalami penurunan jumlah daun planlet pisang raja bulu.

Berdasarkan uji lanjut Duncan Multiple Range Test (DMRT) (Tabel 2), kombinasi perlakuan BAP 1 ppm + IAA 3 ppm memberikan hasil jumlah daun yang berbeda nyata dengan kombinasi perlakuan BAP $0 \mathrm{ppm}+$ IAA 0 ppm, BAP $0 \mathrm{ppm}$ + IAA $3 \mathrm{ppm}$, BAP $1 \mathrm{ppm}+$ IAA 0 ppm, BAP $1 \mathrm{ppm}+$ IAA 1 ppm, dan BAP 0,5 ppm + IAA 3 ppm. Perlakuan BAP 1 ppm + IAA 3 ppm memberikan hasil terbaik pada parameter jumlah daun planlet pisang raja bulu yaitu sebesar 2,75 helai. Hal ini menunjukkan bahwa kombinasi BAP $1 \mathrm{ppm}+$ IAA $3 \mathrm{ppm}$ memberikan pengaruh lebih baik pada jumlah daun planlet pisang dibandingkan dengan penelitian sebelumnya yang dilakukan oleh Triharyanto et al. (2008). Kombinasi IAA 0,5 ppm dan BAP 4 ppm memberikan hasil 0,11 helai pada jumlah daun planlet tanaman pisang raja bulu. Berdasarkan hal tersebut, diketahui bahwa penambahan kombinasi hormon BAP dan IAA dengan konsentrasi yang tepat dapat memacu proses organogenesis pada planlet tanaman. Hal ini sesuai dengan pendapat Zulkarnain (2011) yang menyatakan bahwa usaha yang dapat dilakukan untuk mengatur diferensiasi sel dan pembentukan organ tanaman adalah menambahkan zat pengatur tumbuh auksin dan/atau sitokinin dengan konsentrasi yang tepat pada media kultur jaringan.

Perlakuan BAP 0,5 ppm + IAA 3 ppm dan BAP $0 \mathrm{ppm}+$ IAA $3 \mathrm{ppm}$ memberikan hasil jumlah daun yang tidak berbeda nyata dengan perlakuan BAP $0 \mathrm{ppm}+$ IAA $0 \mathrm{ppm}$. Perlakuan BAP $0 \mathrm{ppm}+$ IAA $0 \mathrm{ppm}$ memberikan hasil jumlah daun planlet pisang raja bulu sebesar 1,15 helai, sedangkan perlakuan BAP 0,5 ppm + IAA 3 ppm dan BAP 0 ppm + IAA 3 ppm memberikan hasil masing-masing sebesar 0,70 dan 0,90 helai daun. Pertumbuhan daun planlet yang rendah diduga karena hormon endogen planlet pisang raja bulu belum cukup untuk memacu pertumbuhan daun, sehingga diperlukan hormon eksogen dengan konsentrasi yang tepat. Hal ini sesuai dengan pendapat Hartati et al. (2017) yang menyatakan bahwa dalam kultur jaringan biasanya ditambahkan hormon eksogen untuk mendukung kinerja hormon endogen yang telah dihasilkan secara alami oleh tanaman.

\section{Jumlah Akar}

Hasil analisis ragam menunjukkan bahwa perlakuan BAP tidak memberikan pengaruh nyata terhadap parameter jumlah akar, sedangkan

Tabel 4. Rata-rata Panjang Akar pada Perlakuan BAP dan IAA

\begin{tabular}{|c|c|c|c|c|c|c|}
\hline \multirow{2}{*}{$\mathrm{BAP}(\mathrm{ppm})$} & \multicolumn{5}{|c|}{ IAA (ppm) } & \multirow{2}{*}{ Rata-rata } \\
\hline & 0 & 1 & 2 & 3 & 4 & \\
\hline 0 & $4.24^{\mathrm{cd}}$ & $7.78^{a b}$ & $8.22^{a b}$ & $\begin{array}{l}-\mathrm{cm}-- \\
1.18^{\mathrm{e}}\end{array}$ & $9.33^{\mathrm{a}}$ & $6.15^{c}$ \\
\hline 0,5 & $8,37^{a b}$ & $7,36^{\mathrm{abc}}$ & $7,87^{\mathrm{ab}}$ & 2,21 de & $9,73^{\text {a }}$ & $7,11^{\mathrm{bc}}$ \\
\hline 1 & $6,70^{a b c}$ & $6,50^{b c}$ & $8,23^{a b}$ & $9,29^{\text {a }}$ & $6,96^{a b c}$ & $7,53^{\mathrm{ab}}$ \\
\hline 1,5 & $8,91^{\mathrm{ab}}$ & $7,33^{a b c}$ & $7,84^{\mathrm{ab}}$ & $9,28^{\mathrm{ab}}$ & $9,27^{\mathrm{ab}}$ & $8,52^{\mathrm{a}}$ \\
\hline 2 & $9,22^{a b}$ & $8,49^{a b}$ & $8,08^{a b}$ & $8,64^{\text {ab }}$ & $7,62^{a b c}$ & $8,41^{\mathrm{a}}$ \\
\hline Rata-rata & $7,49^{\mathrm{a}}$ & $7,49^{\mathrm{a}}$ & $8,05^{\mathrm{a}}$ & $6,12^{\mathrm{b}}$ & $8,58^{a}$ & \\
\hline
\end{tabular}

*Superskrip yang berbeda pada baris rata-rata, kolom rata-rata, dan matriks interaksi menunjukkan perbedaan nyata $(\mathrm{P}<0,05)$. 
perlakuan IAA memberikan pengaruh nyata terhadap jumlah akar planlet pisang raja bulu. Interaksi perlakuan BAP dan IAA memberikan pengaruh nyata terhadap jumlah akar planlet pisang raja bulu, (Tabel 3).

Berdasarkan Tabel 3 diketahui bahwa terdapat pengaruh interaksi antara perlakuan BAP dan IAA terhadap parameter jumlah akar planlet pisang raja bulu (Musa paradisiaca). Perlakuan BAP 0,5 mengalami kenaikan rata-rata jumlah akar pada perlakuan IAA 2 ppm, kemudian mengalami penurunan pada perlakuan IAA $3 \mathrm{ppm}$, dan kembali naik pada perlakuan IAA $4 \mathrm{ppm}$. Sedangkan perlakuan BAP 1 ppm mengalami penurunan pada perlakuan IAA 1 ppm hingga 2 ppm, kemudian mengalami kenaikan pada perlakuan IAA 3 ppm, dan kembali turun pada perlakuan IAA $4 \mathrm{ppm}$. Perlakuan BAP $2 \mathrm{ppm}$ mengalami kenaikan pada perlakuan IAA $1 \mathrm{ppm}$ hingga $2 \mathrm{ppm}$, kemudian mengalami penurunan pada perlakuan IAA 3 ppm namun tidak mengalami kenaikan yang signifikan pada perlakuan IAA 4 ppm.

Berdasarkan uji lanjut Duncan Multiple Range Test (DMRT) (Tabel 3), kombinasi perlakuan BAP $0,5 \mathrm{ppm}+$ IAA $4 \mathrm{ppm}$ memberikan hasil jumlah akar yang berbeda nyata dengan kombinasi perlakuan BAP 0 ppm + IAA 0 ppm, BAP 0 ppm + IAA 3 ppm, BAP 0,5 ppm + IAA 3 ppm, BAP 1 ppm + IAA 2 ppm, dan BAP 2 ppm + IAA 0 ppm. Perlakuan BAP 0,5 ppm + IAA $4 \mathrm{ppm}$ memberikan hasil terbaik pada parameter jumlah akar planlet pisang raja bulu yaitu sebesar 4,20 helai. Hal ini menunjukkan bahwa kombinasi BAP 0,5 ppm + IAA 4 ppm memberikan pengaruh lebih baik pada jumlah akar planlet tanaman pisang dibandingkan dengan penelitian sebelumnya yang dilakukan oleh Lathyfah dan Dewi (2016). Kombinasi IAA 0,6 ppm dengan BAP 3 ppm memberikan hasil jumlah akar planlet pisang barangan sebesar 3,5 helai. Hormon IAA yang lebih tinggi menghasilkan jumlah akar planlet tanaman pisang yang lebih banyak, hal ini menunjukkan bahwa hormon IAA mempunyai peran penting dalam pertumbuhan akar planlet tanaman pisang. Menurut pendapat Putri et al. (2018), hormon IAA merupakan golongan auksin yang berperan dalam diferensiasi sel dan menginisiasi pembentukan akar tanaman.

Perlakuan BAP 0,5 ppm + IAA 3 ppm dan BAP $0 \mathrm{ppm}+$ IAA $3 \mathrm{ppm}$ memberikan hasil jumlah akar yang tidak berbeda nyata dengan perlakuan BAP $0 \mathrm{ppm}+$ IAA $0 \mathrm{ppm}$. Perlakuan BAP $0 \mathrm{ppm}+$ IAA $0 \mathrm{ppm}$ memberikan hasil jumlah akar sebesar 1,70 helai, sedangkan perlakuan BAP 0,5 ppm + IAA 3 ppm dan BAP 0 ppm + IAA 3 ppm memberikan hasil jumlah akar masing-masing sebesar 1,35 dan 2,00 helai. Pertumbuhan akar yang rendah diduga karena produksi hormon endogen planlet pisang raja bulu masih sangat sedikit, sehingga diperlukan hormon eksogen dengan konsentrasi yang tepat. Hal ini sesuai dengan pendapat Ngomuo et al. (2014) yang menyatakan bahwa dalam kultur jaringan biasanya ditambahkan hormon eksogen untuk mendukung kinerja hormon endogen tanaman dalam memacu pertumbuhan planlet tanaman.

\section{Panjang Akar}

Hasil analisis ragam menunjukkan bahwa

Tabel 5. Rata-rata Tinggi Planlet pada Perlakuan BAP dan IAA

\begin{tabular}{|c|c|c|c|c|c|c|}
\hline \multirow{2}{*}{$\mathrm{BAP}(\mathrm{ppm})$} & \multicolumn{5}{|c|}{ IAA (ppm) } & \multirow[t]{2}{*}{ Rata-rate } \\
\hline & 0 & 1 & 2 & 3 & 4 & \\
\hline & & & & cm ----- & & - \\
\hline 0 & $3,75^{\mathrm{f}}$ & 7,23 abc & $6,85^{\text {abcde }}$ & $3,89^{\mathrm{f}}$ & $7,43^{a b c}$ & $5,83^{\mathrm{b}}$ \\
\hline 0,5 & 6,81 abcde & $5,88^{\text {cde }}$ & 6,13 bcde & $3,97^{\mathrm{f}}$ & 7,11 abcd & $5,98^{\mathrm{b}}$ \\
\hline 1 & 6,48 abcde & $5,11 \mathrm{ef}^{-}$ & $5,46^{\text {def }}$ & 6,67 abcde & 5,97 bcde & $5,94^{\mathrm{b}}$ \\
\hline 1,5 & $6,63^{\text {abcde }}$ & $6,82^{\text {abcde }}$ & $7,34^{a b c}$ & 6,87 abcde & $7,65^{a}$ & $7,06^{\mathrm{a}}$ \\
\hline 2 & 6,26 abcde & $6,46^{\text {abcde }}$ & $6,94^{\text {abcd }}$ & $7,50^{a b}$ & 6,65 abcde & $6,76^{\mathrm{a}}$ \\
\hline Rata-rata & $5,98^{\mathrm{bc}}$ & $6,30^{\mathrm{abc}}$ & $6,54^{\mathrm{ab}}$ & $5,78^{\mathrm{c}}$ & $6,96^{\mathrm{a}}$ & \\
\hline
\end{tabular}

*Superskrip yang berbeda pada baris rata-rata, kolom rata-rata, dan matriks interaksi menunjukkan perbedaan nyata $(\mathrm{P}<0,05)$. 
perlakuan BAP dan IAA memberikan pengaruh nyata terhadap parameter panjang akar planlet pisang raja bulu. Interaksi perlakuan BAP dan IAA juga memberikan pengaruh nyata terhadap panjang akar planlet pisang raja bulu, (Tabel 4 .

Berdasarkan Tabel 4 diketahui bahwa terdapat pengaruh interaksi antara perlakuan BAP dan IAA terhadap parameter panjang akar planlet pisang raja bulu (Musa paradisiaca). Perlakuan BAP 0 ppm mengalami kenaikan hasil panjang akar pada perlakuan IAA $1 \mathrm{ppm}$ hingga $2 \mathrm{ppm}$, kemudian mengalami penurunan pada perlakuan IAA 3 ppm, dan mengalami kenaikan kembali pada perlakuan IAA $4 \mathrm{ppm}$. Sedangkan perlakuan BAP 2 ppm mengalami penurunan hasil panjang akar pada perlakuan IAA $1 \mathrm{ppm}$ hingga $2 \mathrm{ppm}$, kemudian mengalami kenaikan pada perlakuan 3 ppm, dan mengalami penurunan kembali pada perlakuan IAA $4 \mathrm{ppm}$. Perlakuan BAP 0,5 ppm mengalami penurunan panjang akar pada perlakuan IAA $3 \mathrm{ppm}$, kemudian mengalami kenaikan pada perlakuan IAA 4 ppm. Sedangkan Perlakuan BAP 1 ppm mengalami kenaikan hasil panjang akar pada perlakuan IAA 2 ppm hingga 3 ppm, kemudian mengalami penurunan pada perlakuan IAA 4 ppm.

Berdasarkan uji lanjut Duncan Multiple Range Test (DMRT) (Tabel 4), kombinasi perlakuan BAP $0,5 \mathrm{ppm}+$ IAA $4 \mathrm{ppm}$ memberikan hasil panjang akar yang berbeda nyata dengan kombinasi perlakuan BAP 0 ppm + IAA 0 ppm, BAP 0 ppm + IAA 3 ppm, BAP 0,5 ppm + IAA 3 ppm, dan BAP 1 ppm + IAA 1 ppm. Perlakuan BAP 0,5 ppm + IAA 4 ppm memberikan hasil terbaik pada parameter panjang akar planlet pisang raja bulu yaitu sebesar 9,73 $\mathrm{cm}$. Hal ini menunjukkan bahwa kombinasi BAP $0,5 \mathrm{ppm}+\mathrm{IAA} 4 \mathrm{ppm}$ memberikan pengaruh lebih baik pada panjang akar planlet tanaman pisang dibandingkan dengan penelitian sebelumnya yang dilakukan oleh Zulkifli et al. (2017). Penambahan BAP 1 ppm memberikan hasil panjang akar planlet pisang klutuk sebesar $6,14 \mathrm{~cm}$. Hal ini menunjukkan bahwa penambahan hormon BAP perlu dikombinasikan dengan hormon IAA dengan konsentrasi yang tepat untuk menghasilkan panjang akar planlet pisang yang lebih baik. Hal ini sesuai dengan pendapat Wattimena (1988) yang menyatakan bahwa kombinasi hormon auksin dan sitokinin dengan konsentrasi yang tepat pada media kultur jaringan dapat memacu pertumbuhan akar planlet tanaman.

Perlakuan BAP $0 \mathrm{ppm}+$ IAA $3 \mathrm{ppm}$ memberikan hasil rata-rata jumlah akar terendah yaitu 1,70 helai. Hal ini menunjukkan bahwa untuk memacu pertumbuhan akar tetap membutuhkan kombinasi hormon BAP dengan konsentrasi yang rendah supaya tidak menghambat kinerja hormon auksin. Hal ini sesuai dengan pendapat Boshale et al. (2011) yang menyatakan bahwa konsentrasi BAP yang terlalu tinggi pada media kultur jaringan dapat mengganggu kinerja auksin dalam memacu aktivitas meristem di ujung akar. Hormon sitokinin dengan konsentrasi yang lebih tinggi akan memacu pembentukan tunas planlet tanaman, sedangkan jika konsentrasi auksin yang lebih tinggi maka akan memacu pertumbuhan tinggi dan panjang akar planlet tanaman. Hal ini sesuai dengan pendapat Jafari et al. (2011) yang

Tabel 6. Rata-rata Diameter Batang pada Perlakuan BAP dan IAA

\begin{tabular}{|c|c|c|c|c|c|c|}
\hline \multirow{2}{*}{ BAP (ppm) } & \multicolumn{5}{|c|}{ IAA (ppm) } & \multirow[t]{2}{*}{ Rata-rata } \\
\hline & 0 & 1 & 2 & 3 & 4 & \\
\hline & & & & & & $0 \Omega$ \\
\hline 0 & $2,42^{\mathrm{f}}$ & $2,611^{\mathrm{ef}}$ & 3,02 bcde & $2,90^{\text {cdef }}$ & 3,28 abcd & $2,84^{b}$ \\
\hline 0,5 & $3,26^{\text {abcd }}$ & 3,39 abc & 3,30 abcd & $3,38^{a b c}$ & $3,28^{\text {abcd }}$ & $3,32^{\mathrm{a}}$ \\
\hline 1 & 3,32 abcd & 3,10 abcde & $3,36^{a b c}$ & $3,60^{\mathrm{a}}$ & 3,07 abcde & $3,29^{\mathrm{a}}$ \\
\hline 1,5 & $3,43^{a b c}$ & $3,22^{\mathrm{abcd}}$ & $3,39 \mathrm{abc}$ & $2,78^{\mathrm{def}}$ & $3,27^{\text {abcd }}$ & $3,21^{\mathrm{a}}$ \\
\hline 2 & $3,10^{\text {abcde }}$ & $3,40^{\mathrm{abc}}$ & $3,53^{\mathrm{ab}}$ & $3,54^{\mathrm{ab}}$ & 3,31 abcd & $3,38^{\mathrm{a}}$ \\
\hline Rata-rata & 3,10 & 3,14 & 3,32 & 3,24 & 3,24 & \\
\hline
\end{tabular}

*Superskrip yang berbeda pada kolom rata-rata, dan matriks interaksi menunjukkan perbedaan nyata $(\mathrm{P}<0,05)$. 
menyatakan bahwa untuk memacu pemanjangan akar, diperlukan konsentrasi auksin yang tinggi dan konsentrasi sitokinin yang rendah.

\section{Tinggi Planlet}

Hasil analisis ragam menunjukkan bahwa perlakuan BAP dan IAA memberikan pengaruh nyata terhadap tinggi planlet pisang raja bulu. Interaksi perlakuan BAP dan IAA juga memberikan pengaruh nyata terhadap tinggi planlet pisang raja bulu, (Tabel 5).

Berdasarkan Tabel 5 diketahui bahwa terdapat pengaruh interaksi antara perlakuan BAP dan IAA terhadap parameter tinggi planlet pisang raja bulu (Musa paradisiaca). Perlakuan BAP 0 ppm mengalami kenaikan hasil tinggi planlet pada perlakuan IAA $1 \mathrm{ppm}$, kemudian mengalami penurunan pada perlakuan IAA 2 ppm hingga 3 ppm, setelah itu mengalami kenaikan kembali pada perlakuan IAA $4 \mathrm{ppm}$. Sedangkan perlakuan BAP $1 \mathrm{ppm}$ mengalami penurunan hasil tinggi planlet pada perlakuan IAA 1 ppm, kemudian menggalami kenaikan pada perlakuan IAA 2 ppm hingga $3 \mathrm{ppm}$, setelah itu mengalami penurunan kembali pada perlakuan $4 \mathrm{ppm}$. Perlakuan BAP $1,5 \mathrm{ppm}$ dan $2 \mathrm{ppm}$ mengalami kenaikan hasil tinggi planlet pada perlakuan IAA 1 ppm hingga 2 ppm. Namun perlakuan BAP 1,5 ppm pada perlakuan IAA 3 ppm mengalami penurunan hasil tinggi tanaman dan mengalami kenaikan pada perlakuan IAA 4 ppm, sedangkan perlakuan BAP 2 ppm mengalami keniakan hasil tinggi planlet pada perlakuan IAA $3 \mathrm{ppm}$ dan mengalami penurunan pada perlakuan IAA 4 ppm.

Berdasarkan uji lanjut Duncan Multiple Range Test (DMRT) (Tabel 5), kombinasi perlakuan BAP $1,5 \mathrm{ppm}+$ IAA $4 \mathrm{ppm}$ memberikan hasil tinggi planlet yang berbeda nyata dengan kombinasi perlakuan BAP 0 ppm + IAA 0 ppm, BAP 0 ppm + IAA 3 ppm, BAP 0,5 $\mathrm{ppm}+\mathrm{IAA} 1 \mathrm{ppm}$, BAP 0,5 ppm + 2 IAA ppm, BAP 0,5 ppm + IAA 3 ppm, BAP 1 ppm + IAA 1 ppm, BAP $1 \mathrm{ppm}+$ IAA 2 ppm, dan BAP $1 \mathrm{ppm}+$ IAA 4 ppm. Perlakuan BAP 0,5 ppm + IAA 4 ppm memberikan hasil terbaik pada parameter tinggi planlet pisang raja bulu yaitu sebesar 7,65 cm. Hal ini menunjukkan bahwa kombinasi BAP 0,5 ppm + IAA 4 ppm memberikan pengaruh lebih baik pada tinggi planlet tanaman pisang dibandingkan dengan penelitian sebelumnya yang dilakukan oleh Lathyfah dan Dewi (2016). Kombinasi IAA 0,3 ppm dengan BAP 3 ppm memberikan hasil tinggi planlet pisang barangan dengan rata-rata sebesar 2,1 cm. Konsentrasi BAP 0,5 ppm yang lebih rendah dari BAP 3 ppm menyebabkan tunas planlet tanaman pisang tidak lagi tumbuh, sehingga pertumbuhan tinggi planlet lebih optimal. Hal ini sesuai dengan pendapat Ramesh dan Ramassamy (2014) yang menyatakan bahwa pembentukan tunas mempengaruhi pertumbuhan tinggi tanaman pisang, semakin banyak tunas yang tumbuh, maka pertumbuhan tinggi tanaman pisang menjadi kurang optimal.

Perlakuan BAP $0 \mathrm{ppm}+$ IAA 0 ppm memberikan hasil rata-rata tinggi planlet terendah yaitu $3,75 \mathrm{~cm}$. Hal ini menunjukkan bahwa penambahan zat pengatur tumbuh merupakan hal yang penting dalam budidaya pisang secara kultur jaringan. Zat pengatur tumbuh berperan dalam memacu pembelahan sel dan pembentukan organ planlet tanaman. Hal ini sesuai dengan pendapat Soesanto dan Rahayuniati (2009) yang menyatakan bahwa penambahan zat pengatur tumbuh pada media kultur jaringan dapat memacu pembelahan sel dan organogenesis planlet tanaman pisang.

\section{Diameter Batang}

Hasil analisis ragam menunjukkan bahwa perlakuan BAP memberikan pengaruh nyata terhadap diameter batang planlet pisang raja bulu, sedangkan perlakuan IAA tidak memberikan pengaruh nyata terhadap diameter batang planlet pisang raja bulu. Interaksi perlakuan BAP dan IAA memberikan pengaruh nyata terhadap parameter diameter batang planlet pisang raja bulu, (Tabel 6).

Berdasarkan Tabel 6 diketahui bahwa terdapat pengaruh interaksi antara perlakuan BAP dan IAA terhadap parameter diameter batang planlet pisang raja bulu. Perlakuan BAP 1 ppm dan 1,5 ppm mengalami penurunan hasil diameter batang pada perlakuan IAA 1 ppm, kemudian mengalami kenaikan pada perlakuan IAA $2 \mathrm{ppm}$. Namun perlakuan BAP $1 \mathrm{ppm}$ tetap mengalami kenaikan hasil diameter batang planlet pada perlakuan IAA $3 \mathrm{ppm}$ dan mengalami penurunan pada perlakuan IAA 4 ppm, sedangkan perlakuan BAP 1,5 ppm mengalami penurunan hasil diameter batang planlet pada perlakuan IAA 3 
ppm dan mengalami kenaikan pada perlakuan 4 ppm. Perlakuan BAP 0 ppm mengalami kenaikan hasil diameter batang planlet pada perlakua IAA 1 ppm hingga $2 \mathrm{ppm}$, kemudian mengalami sedikit penurunan pada perlakuan IAA $3 \mathrm{ppm}$, setelah itu mengalami kenaikan kembali pada perlakuan IAA 4 ppm.

Berdasarkan uji lanjut Duncan Multiple Range Test (DMRT) (Tabel 6), kombinasi perlakuan BAP 1 ppm + IAA 3 ppm memberikan hasil diameter batang yang berbeda nyata dengan kombinasi perlakuan BAP 0 ppm + IAA 0 ppm, BAP 0 ppm + IAA 1 ppm, BAP 0 ppm + IAA 2 ppm, BAP 0 ppm + IAA 3 ppm, dan BAP 1,5 ppm + IAA 3 ppm. Perlakuan BAP 1 ppm + IAA 3 ppm memberikan hasil terbaik pada parameter diameter batang planlet pisang raja bulu yaitu sebesar 3,60 $\mathrm{mm}$. Hal ini menunjukkan bahwa kombinasi BAP $1 \mathrm{ppm}+$ IAA $3 \mathrm{ppm}$ memberikan pengaruh lebih baik pada diameter batang planlet pisang raja bulu dibandingkan dengan penelitian sebelumnya yang telah dilakukan oleh Triharyanto et al. (2018). Kombinasi IAA 0,5 ppm dan BAP 4 ppm memberikan hasil rata-rata diameter batang planlet pisang raja bulu sebesar $2,30 \mathrm{~mm}$. Hal ini menunjukkan bahwa penambahan kombinasi hormon BAP dan IAA dengan konsentrasi yang tepat dapat memacu pertumbuhan planlet melalui proses pembelahan sel tanaman pada kultur in vitro. Hal ini sesuai dengan pendapat Zulkarnain (2011) yang menyatakan bahwa untuk memperoleh pertumbuhan yang optimal, diperlukan konsentrasi ZPT yang tepat dan sesuai dengan kebutuhan tanaman.

Perlakuan BAP 0 ppm + IAA 0 ppm menunjukkan hasil diameter batang planlet terendah yaitu 2,42 $\mathrm{mm}$. Hal ini menunjukkan bahwa penambahan zat pengatur tumbuh sangat penting untuk mendukung pertumbuhan batang planlet pisang raja bulu (Musa paradisiaca). Menurut pendapat Ngomuo et al. (2014), pertumbuhan planlet menjadi kurang maksimal apabila hormon endogen pada tanaman belum mencukupi kebutuhan untuk memacu pertumbuhan, oleh karena itu diperlukan hormon eksogen untuk mendukung kinerja hormon endogen tanaman.

\section{KESIMPULAN DAN SARAN}

Berdasarkan hasil yang diperoleh, dapat disimpulkan bahwa terdapat pengaruh interaksi perlakuan BAP dan IAA terhadap parameter pertumbuhan planlet pisang raja bulu (Musa paradisiaca). Kombinasi perlakuan BAP 1 ppm + IAA 3 ppm memberikan pengaruh nyata terbaik pada parameter jumlah daun dan diameter batang, sedangkan kombinasi perlakuan BAP 0,5 ppm + IAA 4 ppm memberikan pengaruh nyata terbaik pada parameter panjang akar dan jumlah akar. Kombinasi perlakuan BAP 1,5 ppm + IAA 4 ppm memberikan pengaruh nyata terbaik pada parameter tinggi planlet tanaman pisang raja bulu (Musa paradisiaca). Konsentrasi ZPT yang direkomendasikan untuk kultur jaringan tanaman pisang raja bulu (Musa paradisiaca) pada tahap pengakaran yaitu BAP 0,5 - 1,5 ppm yang dikombinasikan dengan IAA $3-4$ ppm.

\section{DAFTAR PUSTAKA}

Ahmed, S., S. A. K. Singh, V. K. Wali, and P. Kumari. 2014. In vitro multiplication of banana (Musa sp.) cv. Grand Naine. J. Biotechnology, 13 (27): 2696 - 2703.

Al-Amin, M. D., M. R. Karim, M. R. Amin, S. Rahman, and A. N. M. Mamun. 2009. In vitro micropropagation of banana. J. Agri. Res. 34(4): $645-659$.

Anbazhagan, M., B. Balachandran, and K. Arumugam. 2014. In vitro propagation of Musa sp (Banana). J. Current Microbiology and Applied Sciences 3(7): 399 - 404.

Bhosale, U. P., S. V. Dubhashi, N. S. Mali, and H. P. Rathod. 2011. In vitro shoot multiplication in different species of banana. Asian J. Plant Sci. 1(3): 23 - 27.

Hartati, S, R.B. Arniputri, L.A. Soliah, and Cahyono. 2017. Effects of organic additives and naphthalene acetid acid (NAA) application on the in vitro growth of black orchid hybrid (Coelogyne pandurata L.). Bulgarian J. Agri. Sci. 23(6): 951 - 957.

Jafari, N, R. Y. Othman, and N, Khalid. 2011. Effect of benzylaminopurine (BAP) pulsing on in vitro shoot multiplication of Musa 
acuminata (Banana) cv. Berangan. Afr J. Biotechnol 10(13): 2446 - 2450.

Lathyfah, U. dan E. R. S. Dewi. 2016. Pengaruh variasi konsentrasi Indole Acetid Acid (IAA) terhadap pertumbuhan tunas pisang barangan (Musa acuminata triploid aaa.) dalam kultur in vitro. J. Bioma 5(1): $32-$ 42.

Ngomuo, M., E. Mneney, and P. Ndakidemi. 2013. The effect of auxins and cytokinin on growth and development of (Musa sp.) var."Yangambi" explanted in tissue culture. American J. Plant Sci. 4(1): 2174 - 2180.

Putri, R. R. D., Suwirnem, dan N. Nasril. 2018. Pengaruh Naphthalene Asam Asetat (NAA) pada pertumbuhan akar pisang Raja Kinalun secara in vitro. J. Bio. Univ. Andalas 6(1): $1-5$.

Ramesh, Y., and V. Ramassamy. 2014. Effect of gelling agents in in vitro multiplication of banana var. Poovan. Int. J. Advanced Bio. research 4(3): $308-311$.

Soesanto, L. dan F. R. Rahayuniati. 2009. Pengimbasan ketahanan bibit pisang ambon kuning terhadap penyakit layu fusarium dengan beberapa jamur antagonis. J. HPT Tropika. 9(2): $130-$ 140.

Saparinto, C. dan R. Susiana. 2016. Grow Your Own Medical Plant - Panduan Praktis Menanam 51 Tanaman Obat Populer di Pekarangan. Lily Publisher. Yogyakarta.
Triharyanto E., B. A. Retno, S. M. Endang, and T. Ellyvia. 2018. Kajian konsentrasi IAA dan BAP pada multiplikasi pisang raja bulu in vitro dan aklimatisasinya. J. Agrotech. Res. 2(1): $1-5$.

Wattimena, G. A. 1988. Zat Pengatur Tumbuh pada Tanaman. Laboratorium Kultur Jaringan Pusat Antar Universitas Bioteknologi IPB. Bogor.

Yatim, H. 2016. Multiplikasi pisang raja bulu (Musa paradisiaca L. AAB GROUP) pada beberapa konsentrasi Benzyl Aminopurine (BAP) secara in vitro. J. Agroekoteknologi 4(3): 1989 - 1995.

Yudha, H., S. Rahayu, dan S. Hannum. 2015. Induksi tunas pisang barangan (Musa acuminata L.) dengan pemberian NAA dan BAP berdasarkan sumber eksplan basal. J. Biosains 1(2): $13-18$.

Yuliarti, N. 2010. Kultur Jaringan Tanaman Skala Rumah Tangga. ANDI. Yogyakarta.

Zulkarnain. 2011. Solusi Perbanyakan Tanaman, Budidaya Kultur Jaringan Tanaman. Bumi Aksara. Jakarta.

Zulkifli, Herman, dan P. L. Sari. 2017. Pengaruh konsentrasi bayclin pada pencucian ii dan bap pada media ms terhadap pertumbuhan eksplan tanaman pisang klutuk (Musa paradisiaca. L) secara in vitro. J. Riau Biologia 2(2): 106 - 111. 